Published in final edited form as:

J AAPOS. 2018 December ; 22(6): 483-484. doi:10.1016/j.jaapos.2018.07.347.

\title{
CATARACT DEVELOPMENT ASSOCIATED WITH LONG-TERM GLUCOCORTICOID THERAPY IN DUCHENNE MUSCULAR DYSTROPHY PATIENTS
}

\author{
Tuy Nga Brignol, MD, \\ AFM-Téléthon, Evry, France
}

Patrice E. Fort, PhD,

Department of Ophthalmology and Visual Sciences, University of Michigan, and Molecular and Integrative, Physiology, Kellogg Eye Center, Ann Arbor, Michigan

\section{Dora Fix Ventura, PhD,}

Department of Experimental Psychology, Institute of Psychology, Universidade de São Paulo, Brazil

Ramin Tadayoni, MD, PhD, and Ophthalmology Department, Université Paris, Lariboisiére, Saint Louis \& Cochin Hospitals (APHP), OphtalmoPôle Paris, Académie Nationale de Chirurgie

\section{Alvaro Rendon, PhD \\ Sorbonne Université, INSERM, CNRS, Institut de la Vision, Paris, France}

To the Editor. We read with interest the recent article by Rice and colleagues ${ }^{1}$ reporting on 596 patients with Duchenne muscular dystrophy (DMD) treated with steroid and evaluated for cataract development. The authors reported that the prevalence of cataracts was $25.1 \%$ in patients receiving deflazacort compared with $12.6 \%$ of those on prednisone. Only 7 patients $(1.4 \%)$ required cataract surgery at a mean age of 16.9 years, and all of them were on deflazacort. Although, as pointed out by the authors, this suggests a link between steroid administration and cataract development, a potential influence of the position of the DMD gene mutation cannot be excluded.

Correlations between ocular phenotypes and position of the mutation have been previously suggested. First, in regard to the retina, abnormal dark-adapted electroretinograms (ERGs) were reported to be more frequent in DMD and Becker muscular dystrophy patients with more distal mutations. ${ }^{2}$ More recently, it is the prevalence of red-green color defect among DMD patients that was reported to be associated with deletion downstream of exon $30 .^{3}$

Relative to the ocular lens, position study in DMD gene mutant and transgenic mice revealed a differential cataract prevalence in mice lacking the main product $(\mathrm{mdx})^{4}$ or the more distal one (Dp71-null mice), with, for the latter, progressive cataract due to loss of lens fibers' organization. ${ }^{5}$ This particularly critical role of Dp71 in the lens is consistent with the relative roles of distal dystrophins isoforms in human retina.

Based on the existing literature, it would be important, first, to determine precisely retinal function (color vision, electroretinography, retinal optical coherence tomography) and 
genotype of the 7 patients who required cataract surgery; and, second, to identify patients with deletion downstream of exon 30 of dystrophin gene in patients receiving deflazacort group and those on prednisone.

Such complementary studies could indeed identify a subgroup of DMD patients for whom deflazacort is a risk factor for surgery-requiring cataract formation. Additionally, an association similar to that with ERG could also establish that, in absence of full genotyping, retinal function assessment in DMD patients could be a viable option to identify those patients at risk of complication associated with long-term glucocorticoid treatment.

\section{References}

1. Rice ML, Wong B, Horn PS, Yang MB. Cataract development associated with long-term glucocorticoid therapy in Duchenne muscular dystrophy patients. J AAPOS 2018;22:192-6. [PubMed: 29733899]

2. Pillers DA, Fitzgerald KM, Duncan NM, et al. Duchenne/Becker muscular dystrophy: correlation of phenotype by electroretinography with sites of dystrophin mutations. Hum Genet 1999;105:2-9. [PubMed: 10480348]

3. Costa MF, Oliveira AG, Feitosa-Santana C, Zatz M, Ventura DF. Red-green color vision impairment in Duchenne muscular dystrophy. Am J Hum Genet 2007;80:1064-75. [PubMed: 17503325]

4. Kurihara T, Kishi M, Saito N, Komoto M, Hidaka T, Kinoshita M. Electrical myotonia and cataract in X-linked muscular dystrophy (mdx) mouse. J Neurol Sci 1990;99:83-92. [PubMed: 2250175]

5. Fort PE, Darche M, Sahel JA, Rendon A, Tadayoni R. Lack of dystrophin protein Dp71 results in progressive cataract formation due to loss of fiber cell organization. Mol Vis 2014;20:1480-90. [PubMed: 25489223] 